\title{
Güzel Sanatlar Lisesi Resim Bölümü Öğrencilerinin Cinsiyet Kalıp Yargıları:Metafor Analizi ve Resim Çizme-Yazma Yöntemi ${ }^{1}$
}

\section{Gender Stereotypes of Students of The Fine Arts High School Painting Department: Metaphor Analysis and Drawing-Writing Method}

\author{
Eray GÜNAY, Özge ODABAŞI KOÇ* \\ ${ }^{1}$ Öğrenci, Van Güzel Sanatlar Lisesi, eraycan226@gmail.com, 0000-0001-5138-7098 \\ ${ }^{2}$ Uzman Felsefe Grubu Öğretmeni, Van Güzel Sanatlar Lisesi, ozgeodabasi@hotmail.com, 0000-0003-2985- \\ 9903, *Sorumlu Yazar
}

Geliş tarihi/Received : 02.12.2021 Kabul tarihi/Accepted: 22.06.2021 Yayın tarihi/Published: 30.06.2021

\section{ÖZET}

Bu çalıșmanın amacı Güzel Sanatlar Lisesi öğrencilerinin cinsiyet kalıp yargılarının incelenmesidir. Araștırmanın çalışma grubu Van ilinde bulunan Güzel Sanatlar Lisesi’nin resim alanında öğrenim gören öğrenciler arasından\%37'sini kız, \%63'ünü erkek gönüllü 89 öğrenci oluşturmaktadır. Bu öğrencilere kadın ve erkeği neye, neden benzettiklerini soran metafor anketi verilmiştir. 'Kadın Çiz', 'Erkek Çiz' etkinliği yapılmıştır. Elde edilen verilerin nitel analiz yöntemlerinden içerik analizi aracilığıyla sınıflanmasıyla elde edilen araştırma sonuçların cinsiyete ve araştırmada kullanılan yöntemlere göre farklılık gösterdiği saptanmıştır. Kadın için 67 erkek için 80 metafor üretilmiştir. Erkeğe üretilen metaforlar daha fazla çeşitlilik göstermektedir. Kız ve erkek öğrencilerin kadını açıklarken ağılıklı olarak bitki, erkeği açıklarken ağırlıklı olarak nesne kategorisindeki metaforları kullandığı görülmüştür. Metafor açıklamalarında ve resim çizimlerinde kız öğrenciler çoğunlukla kadını olumsuz özelliklerle nitelendirmemiştir. Kız öğrencilerin kendilerine yönelik algısı olumlu olduğu düşünülmektedir. Olumsuz özelliklerle erkeğin nitelendirilmesi kız öğrencilere göre daha fazla erkek öğrenci tarafından yapılmıştır. Resim çizimlerinde kız öğrenciler kadını özgür, özsaygısı yüksek, yetenekli, güçlü; erkeği dürüst, saygılı, kadına değer veren olarak nitelendirmiştir. Erkek öğrenciler kadını ev işleri yapan, çocuk bakımıyla ilgilenen, narin, duygusal; erkeği güçlü, koruyan, kahraman, çalışan, para kazanan olarak nitelendirmiştir.

Anahtar Kelimeler: Güzel Sanatlar Lisesi, Cinsiyet, Kalıp Yargı, Metafor, Resim

\begin{abstract}
The aim of this study is to examine the gender stereotypes of students in Fine Arts High School. The sample of the study consists of 89 volunteer students (37\% female and 63\% male) among the students studying in the field of art of the Fine Arts High School located in Van, Turkey. A metaphorical questionnaire asking what and why they liken men and women to was given. An activity of "Draw A Woman" and "Draw A Man" was held. It was determined that the results of the study obtained by classifying the data with the content analysis, one of the qualitative analysis methods, differed according to gender and the methods used in the study. A total of 67 metaphors were created for women and 80 metaphors were created for men. The metaphors created for men had more diversity. It was observed that male and female students mainly used metaphors mainly in the category of plants to describe women, and in the category of objects to describe men. In the explanations and drawings of metaphors, female students mostly did not describe women with negative characteristics. This indicated that female students' self-perception was positive. Compared to female students, male students described men with negative characteristics more. The female students depicted women as independent, talented and strong with a high level of self-esteem while they described men as honest, respectful, and valuing women. On the other hand, male students associated women with housework, childcare, delicacy, and emotionality while they depicted men as strong, protective, heroic, worker, and income earner.
\end{abstract}

Keywords: Fine arts high school, gender, stereotype, metaphor, painting

\footnotetext{
${ }^{1} \mathrm{Bu}$ çalışma birinci yazarın "TÜBİTAK 51. Lise Öğrencileri Araştırma Projeleri Yarışması" psikoloji alanında Van bölge ikinciliği alan "Güzel Sanatlar Lisesi Resim Bölümü Öğrencilerinin Cinsiyet Kalıp Yargllarl: Metafor Analizi ve Resim Çizme-Yazma Yöntemi” adlı proje raporundan üretilmiştir.
} 


\section{GÍRIS}

Toplumdaki kalıp yargılar, kadınları ve erkekleri belirli kalıplar içinde algılamaya yol açar. $\mathrm{Bu}$ kalıplar toplumdan topluma değişir. Cinsiyetler arasında varlığı kabul edilen farklılıkların hepsi biyolojik yapıya indirgenemez. Sosyal çevrenin kız ve erkek çocuklarla ilişki kurma biçimi de onların farklı yetişmelerinde önemli bir etken olur. Örneğin, erkek çocukların bebekle, kız çocukların kamyon ve inşaat oyuncaklarıyla oynaması önlenir. Cinsiyetler arasında davranış ve özellik farklılıkları konusunda insanların kalıplaşmış algılayış biçimleri vardır (Cüceloğlu, 2008, s.387-393). Cinsiyet (sex) terimi, kadın ya da erkek olmanın biyolojik yönünü ifade eder ve biyolojik bir yapıya karşılık gelir. Cinsiyet, bireyin biyolojik cinsiyetine dayalı olarak belirlenen demografik bir kategoridir. Toplumsal cinsiyet (gender) terimi ise kadın ya da erkek olmaya toplumun ve kültürün yüklediği anlamları ve beklentileri ifade eder; kültürel bir yapıyı karşılar ve genellikle bireyin biyolojik yapısıyla ilişkili bulunan psikolojik özelliklerini de içerir. Toplumsal cinsiyet, bireyi kadınsı ya da erkeksi olarak karakterize eden psikososyal özelliklerdir (Rice, 1996'dan akt, Dökmen, 2010, s.19-20).

"Ergenlik dönemi, erinlik ile başlayıp yetişkinliğe kadar süren bir dönemi kapsamakta, çocuklukla yetişkinlik arasında bir geçiş dönemi oluşturmaktadır. Havighurst'a göre ergenlik döneminde tamamlanması gereken psikososyal görevlerden bir tanesi de kadın veya erkek cinsiyet rolünü kazanmadır. Kadın nedir? Erkek nedir? Kadın ve erkeğin dış görünümleri nasıl olmalıdır? Kadın ve erkek nasıl davranmalı, hangi rolleri üstlenmelidir? Ergenlerin olgunlaşma sürecinin bir bölümü, kültürün değișen cinsiyet rollerini inceleyebilme ve hangi cinsiyet rollerini benimseyeceğine karar verme süreçlerini içerir', (İnanç, vd., s.229-231). Bu nedenle ergenlerin bu süreci sağlıklı temellendirmeleri için algılarının belirlenmesi gerekir.

İlgili literatüre bakıldığında okul öncesi dönemdeki çocukların cinsiyetlere dair algılarında resim çizme yöntemi kullanılan çalışmalar görülmektedir (Karapekmez vd., 2018; Güder, 2014;). Çocuklar genel olarak olumlu özellikleri erkeklere, olumsuz ve yetersiz özellikleri kadınlara yüklemişlerdir. Kadınlara en uygun gördükleri meslek aşçı, erkelere en uygun görülen meslek itfaiyecidir. Çocuklar kadınları çok işi olan, dikkatsiz, korkak, güçsüz, zayıf, yetersiz, ağlayan, erkeğe yardım eden, korunması gereken olarak, erkekleri ise dikkatli, güçlü, cesur, ağlamayan, çözüm üreten olarak tanımlamışlardır (Güder, 2014). Kadın ve erkeğin yaptığı mesleklerde ise en çok hekim mesleğinin çizildiği görülmektedir. Kız çocukları kadınlara hekimliği uygun bulurken, erkek çocuklarının erkeklere uygun buldukları meslekler itfaiyecilik ve pilotluktur (Karapekmez vd., 2018). Ebeveynlerin sahip oldukları toplumsal cinsiyet algılarının okulöncesi dönemdeki çocuklarının oyuncak tercihlerine ve cinsiyet özelliklerine ilişkin kalıp yargılarına etkisi incelendiği araştırma sonuçlarına göre ebeveynlerin toplumsal cinsiyet algısının çocukların cinsiyet kalıp yargılarına bir etkisinin olmadığı ve çocuklardaki kalıp yargıların cinsiyete göre anlamlı bir şekilde değişim göstermediği sonucuna varılmıştır (Menekşe ve Asan, 2019). Lise öğrencileri (Dikme ve Gökçe 2019; Filiz vd. 2018; Kantoğlu vd., 2018) üzerinde yapılan çalışmalar görülmektedir. Filiz vd. (2018) tarafından yapılan çalışmada kadının siyasi temsili, liderlik özelliği, kadın-erkek rol ve sorumluluklarındaki ayrım, kadının aile içindeki karar mekanizmasına etkisi ve geleneksel kalıp yargılar konusunda öğrenciler arasında zıt görüşler tespit edilmiştir. Erkeğe daha fazla ekonomik sorumluluk yüklemiştir. Dikme ve Gökçe (2019) tarafından yapılan çalışmaya katılan lise öğrencileri kadını hassas, kırılgan, fedakar, aileyi toparlama, ev işlerinden sorumlu, kısıtlana; erkeği güçlü, dayanıklı, öfkeli, ayrıcalıklı, özgür vb. olarak vurgulanmıştır. Kantoğlu vd. (2018) tarafından yapılan çalışmaya katılan 12-17 yaş arasındaki ergenlerin yaşının artması ile eşitlikçi rolleri benimsemeleri arasında paralellik bulunmaktadır. Düşük eğitim düzeyi ve düşük ekonomik gelire sahip ailelerin çocuklarının toplumsal cinsiyet rollerine ilişkin daha çok "geleneksel cinsiyet rolü” algısına sahip olduğu; annenin çalıştığı, eğitim düzeyi ve ekonomik geliri yüksek ailelerin çocuklarının ise daha çok "eşitlikçi cinsiyet rolü” algısına sahip olduğu saptanmıştır. 
Metafor tekniği kullanılarak, çalışma grubu 18 yaş ve üzeri bireyler (Yeşilkayalı vd. 2019; Sargın, 2018; Direk ve Irmak, 2017; Esen vd. 2017; Topuz, Erkanlı, 2016; Sakallı Ugurlu, Türkoğlu, 2016; Aslan, 2015; Sözer ve Özkan, 2014) olan çalışmalar görülmektedir. Topuz ve Erkanlı'nın (2016) çalışmasında kadın, kırılgan, ilgiye ve bakıma muhtaç, bağımlı, çalışkan ve sorumluluk sahibi ve yaşamın devamlılığını sağlayan olarak tanımlanmıştır. Erkek; yönetenyönlendiren, koruyucu, sahiplenici, mücadeleci, ailesinin sorumluluğunu üstlenen, mantıklı, duygularını göstermeyen, fiziksel güç kullanabilen, başına buyruk, yüceltilen olarak tanımlanmıştır. Bir başka çalışmada lisans öğrencilerinin kadına dair en fazla ürettikleri metafor 'arı' olmuştur. En çok üretilen metaforlara bakıldığında; kadınlarda 'gül', erkekler ise 'çiçek' metaforunu üretmiştir (Sözer ve Özkan, 2014). Araştırmaya katılan öğretmen adayları kadınları "zayıf, hassas ve ilgiye muhtaç" olduğunu vurgulayan metaforlarla tanımlamışlardır. Burada en fazla kullanılan metafor “çiçek”tir (Aslan, 2015). Bekar kadın utangaç, kırılgan, hanım hanımcık, baskılanan/bağımlı, eğlenceli, özgürlüğüne düşkün, çalışkan, genç, güzel, bakımlı tanımlanırken; evli kadınlar için fedakar, sadık, anne, ev hanımı, ailesine bağlı, kocasına bağımlı, şişman, bakımsız, çalışkan, olgun/oturaklı, pasif olarak tanımlanmıştır (Sakallı Uğurlu ve Türkoğlu, 2016). Kadın katılımcılar kendilerine ilişkin olumlu metaforlar üretirken (örneğin; cennet kuşu, inci, benzersiz varlık gibi), erkek katılımcıların daha çok olumsuz anlam içeren metafor (Örneğin; şeytan, saatli bomba, canavar, volkan ve yağmur gibi.) ürettikleri görülmüştür (Sargın, 2018). Araştırmaya katılan Sosyal Hizmet Bölümü öğrencilerinin en fazla "kadını duygusal, merhametli, kırılgan ve sevgiye muhtaç olarak tanımlayan" kategorisinde metafor üretmiş oldukları görülmüştür. Bu kategoride ise en fazla "çiçek" metaforunun kullanılmış olduğu tespit edilmiştir (Yeşilkayalı vd., 2019). Erkekleri, "kaba, sert ve duygusuz" olduğunu vurgulayan metaforlarla tanımlamışlardır. Burada en fazla kullanılan metafor "odun"dur. Ayrıca her iki cinsin kendilerine ilişkin algıları büyük oranda olumluyken, karşı cinse ilişsin algılarının büyük oranda olumsuz olduğu görülmüştür (Aslan, 2015). Bekar erkeklerin hareketli, eğlenceli, sapık, sorumsuz, cesur, mert, çekici, bakımlı, güçlü, çapkın, özgür; evli erkeklerin ise sorumluluk sahibi, baba, aile reisi, iktidar, sert, özgür, fedakar, sadık, güvenilir, olgun/oturaklı, çalışkan, kendine güvenen, göbekli, bıyıklı tanımlandığ 1 görülmüştür (Sakallı Uğurlu ve Türkoğlu, 2016). Esen vd., (2017) tarafından yapılan çalışmanın sonucuna göre kadın katılımcıların çoğu, ev işlerini kendi sorumluluğu olarak görmektedir. Araştırmada elde edilen çarpıcı bulgulardan bir diğeri ise kadınların yaklaşık 1/3'ünün; erkeklerin \%50'den fazlasının kadınların erkekler tarafından korunması gerektiği düşüncesine katıldıklarını ifade etmiş olmalarıdır. Erkeklerin yaklaşık \%50'si evin reisinin erkek olması gerektiğini düşünürken; kadınlarda bu oran yaklaşık \%8'dir. Direk ve Irmak (2017) tarafindan yapılan çalışma sonuçlarına göre kadın öğrencilerin erkek öğrencilere göre toplumsal cinsiyet rolleri açısından eşitlikçi bir tutuma sahip olduğu, bu tutumun ortaya çıkmasında kadın olmak ve annenin eğitimi gibi değişkenlerin en önemli yordayıcılar olduğu gösterilmiştir. Sonuç olarak, yapılan çalışmalarda çoğunlukla katılımcılar kadını narin, duygusal, ev işi yapan, çocuk bakan, korunması gereken olarak nitelerken; erkeği güçlü, koruyan, para kazanan, sert, cesur olarak nitelendirmektedir.

Güder (2014) tarafindan yapılan 'Okul Öncesi Dönemdeki Çocukların Toplumsal Cinsiyet Algılarının İncelenmesi', Karapekmez vd.(2018) tarafından yapılan 'Okul Öncesi Dönemde Mesleklere İlişkin Toplumsal Cinsiyet Algısı' adlı çalışmalarda okul öncesi dönemdeki çocuklara resim çizme tekniği kullanılmıştır. Güzel sanatlar lisesi resim bölümü öğrencilerinin cinsiyet kalıp yargılarının belirlendiği bu çalışmanın söz konusu çalışmalarla benzerliği resim çizme tekniğinin kullanılması, farkları ise resim çizme tekniğinin lise düzeyine uygulanmasıdır. Özkan ve Sözer (2014) tarafından yapılan 'Öğretmen Adaylarının Kadın Olgusuna İlişkin Algılarının Belirlenmesi', Sargın (2018) tarafından yapılan 'Üniversite Öğrencilerinin Kadın Kavramına İlişkin Metaforları: Necmettin Erbakan Üniversitesi Örneği', Yeşilkayalı vd. (2019) tarafından yapılan 'Sosyal Hizmet Bölümü Öğrencilerinin Toplumsal Cinsiyet 
Bağlamında Kadın Algısı: Metafor Analizi Örneği’ adlı çalışmalar üniversite öğrencilerinin kadın algısını belirlemek için metafor tekniği kullanılarak yapılmıştır. Çalışmanın, bu çalışmalarla benzerliği metafor tekniğinin kullanılmış olması, farkı ise resim çizme ve yazma tekniğini kullanılması, lise düzeyinde öğrenim gören öğrenciler üzerinde yapılmış olmasıdır ve sadece kadın algısına değil erkeğe dair algıda ele alınmıştır. Her iki cinsiyeti ele alması yönüyle Aslan (2015) tarafından yapılan 'Öğretmen Adaylarının Toplumsal Cinsiyet Algılarına İlişkin Metaforik Bir Çözümleme', Sakallı Uğurlu, Türkoğlu (2016) tarafından yapılan 'Günümüz Türkiye'sinde Cinsiyet Kalıp Yargıları: Kadın Kimdir? Erkek Kimdir?' adlı çalışmalarla benzerlik göstermektedir. Ayrıca hem lise öğrencilerinin hem de güzel sanatlar lisesi resim bölümü öğrencilerinin cinsiyet kalıp yargıları üzerinde bir çalışmaya rastlanılmadığından, metafor tekniği ve resim çizme-yazma tekniğinin birlikte kullanılması yönüyle ilk çalışma olması sebebiyle önem taşımaktadır.

Bu doğrultuda Güzel Sanatlar Lisesi resim bölümü öğrencilerinin cinsiyet kalıp yargılarını belirlemek amacıyla yapılan çalışmanın hipotezleri şu şekilde sıralanmıştır:

1. Güzel Sanatlar Lisesi resim bölümü öğrencilerinin cinsiyet kalıp yargılarını belirlemede metafor ve resim çizme-yazma teknikleri arasında fark yoktur.

2. Güzel Sanatlar Lisesi resim bölümü öğrencilerinin cinsiyetinin, cinsiyet kalıp yargıları üzerinde etkisi yoktur.

\section{YÖNTEM}

Bu bölümde araştırmanın modeli, çalışma grubu, verilerin toplanması, verilerin analizi ile ilgili bilgiler yer almaktadır.

\section{Araştırmanın Modeli}

Bu araştırmada, Güzel Sanatlar Lisesi resim bölümü öğrencilerinin cinsiyet kalıp yargılarının belirlemek amacıyla nitel araştırma yöntemlerinden fenomenoloji (olgu bilim) kullanılmıştır. Fenomenoloji kişilerin bir olgu ile ilgili deneyimlerinin ortak anlamını tanımlar (Büyüköztürk, 2016).

\section{Çalışma Grubu}

Van ilinde bulunan Güzel Sanatlar Lisesi'nin resim alanında öğrenim gören öğrenciler arasından gönüllü 89 öğrenci araştırmanın çalışma grubunu oluşturmaktadır. Katılımcıların yaşları 14-19 arasında değişmektedir. Çalışmaya dahil edilen katılımcıların yaş ortalaması $15.30 \pm 1.22$ 'dir. Çalışma grubunun cinsiyet ve sınıfa göre dağılımı, Tablo 1'de verilmiştir.

Tablo 1. Çalışma Grubu

\begin{tabular}{lccccc} 
& 9. sinif & 10. sinif & 11. sinıf & 12. sinıf & Toplam \\
\hline Kiz & 13 & 6 & 6 & 8 & 33 \\
\hline Erkek & 17 & 16 & 14 & 9 & 56 \\
\hline Toplam & 30 & 22 & 20 & 17 & 89 \\
\hline
\end{tabular}

Tablo 1'e bakıldığında araştırmaya 89 öğrenci katılmıştır. Bu öğrencilerin 33'ünü kız, 56'sını erkek öğrenciler oluşturmaktadır. Öğrenci sayısının artandan azalana göre sirasıyla 9., 10., 11.,12. sinıflarda olduğu görülmektedir.

\section{Verilerin Toplanması}

Çalışma 2019-2020 Eğitim-Öğretim yılı güz döneminde gerçekleştirilmiştir. Uygulama için gerekli izinler Van İli Tuşba İlçe Milli Eğitim Müdürlüğü’nden alınmıştır. Araştırmaya katılan 89 öğrenciden $85^{\prime}$ 'i 18 yaş altı olduğu için veli izin formu katılımcıların velilerine 
imzalatılmıştır. Öğrencilerden elde edilen verilerin sadece araştırma için kullanılacağı belirtilmiştir. Öğrencilerin gönüllü katıldığına dair belge imzalatılıp istediklerinde çekilebilecekleri bilgisi verilmiştir.

$\mathrm{Bu}$ araştırmada verilerin toplanmasında açı uçlu sorular ve öğrencilerin yapmış oldukları resimler kullanılmıştır. Metafor anketi ve resim çizme-yazma tekniği ile veriler toplanmıştır. Metaforların elde edilmesi için öncelikle öğrencilere "Kadın...................gibidir/benzerdir. Çünkü....................", "Erkek............ ..gibidir/benzerdir.Çünkü........................" biçiminde boşluk doldurmalı cümlelerin olduğu metafor anketi verilmiştir. Kişisel bilgiler olarak da cinsiyet ve sınıfinı yazmaları istenmiştir. Metafor kavramı hakkında bilgilendirme yapıldıktan sonra 20 dakika süre verilmiştir. Daha sonra A4 kağıdı dağıtılarak ikiye katlamaları söylenmiștir. A5 boyutuna gelen kağıda uygulamaları için kadın çiz-erkek çiz yönergesi verilmiş ve çizdiklerini açılayan cümlelerini çizimlerinin olduğu kağıda yazmaları istenmiştir. Bu etkinlik için 40 dakika süre verilmiştir. Kullanılacakları kalem konusunda sınırlandırmaya gidilmemiştir.

\section{Verilerin Analizi}

Verilerin analizinde nitel araştırma yöntemlerinden içerik analizi kullanılmıştır. "İçerik analizinin uygulanması birtakım aşamalar halinde gerçekleşmektedir. Araştırmacı ilk aşamada hedefleri belirlemek zorundadır. İkinci aşama, örneklemin oluşturulması şeklinde ifade edilir. Üçüncü aşamada, örneklemin bölüneceği birimler, maddeler ya da kayıt birimleri ve kategorilerin toplanacağı kategoriler saptanır. Kategorilerin frekansları nicel olarak belirlendikten sonra değerlendirme, çıkarsama ve yorumlama aşamasına gelinilir" (Bilgin, 2014, s.11). Veri analizi için metafor ve çizimler incelemiş, boş bırakılan, herhangi bir düşünceyi ifade etmeyen kağıtların bulunmadığı görülmüştür. Daha sonra kağıtlara 1'den 89'a kadar numara verilmiştir. Sınıf, cinsiyeti ve verilen numara ile alıntılar belirtilmiştir.

Güzel Sanatlar Lisesi resim bölümü öğrencilerinin cinsiyet kalıp yargılarını belirlemek amacıyla serbest düşünmelerini sağlayacak metafor ve resim çizme teknikleri kullanılarak elde edilen veriler kategoriler halinde sınıflanmıştır. Aynı resim ve açıklamalarda birden fazla kategoriye dair veri bulunduğu için ilgili kategorilerde yer verilmiştir. Birimlere ve kategorilere dair gösterilme sıklıklarını saptamak için frekans analizi kullanılmıştır. Frekans analizi, birim veya öğelerin sayısal, yüzdesel ve oransal bir tarzda görülme sıklığını ortaya koymaktır. Bu, belirli bir öğenin yoğunluğunu ve önemini anlamayı sağlar (Bilgin, 2014, s.18).

\section{BULGULAR ve TARTIŞMA}

$\mathrm{Bu}$ bölümde metafor analizi ve resim çizme-yazma uygulamasının bulgularına, metafor ve resimlerinden örneklerle yer verilmiştir.

\section{Kadın İçin Üretilen Metaforlara İlişkin Bulgular}

$\mathrm{Bu}$ alt bölümde araştırmaya katılan kız ve erkek öğrencilerin kadına ilişkin kullandıkları metaforlar ve açıklamalarının kategorilerine, öğrencilerin ifadelerinden alıntılara yer verilmiştir. Metaforlardan elde edilen kategoriler Tablo 2'de ve metafor açıklamalarından elde edilen kategoriler Tablo 3'te yer alır. 
Tablo 2. Öğrencilerin Kadın İçin Kullandıkları Metafor ve Kategorileri

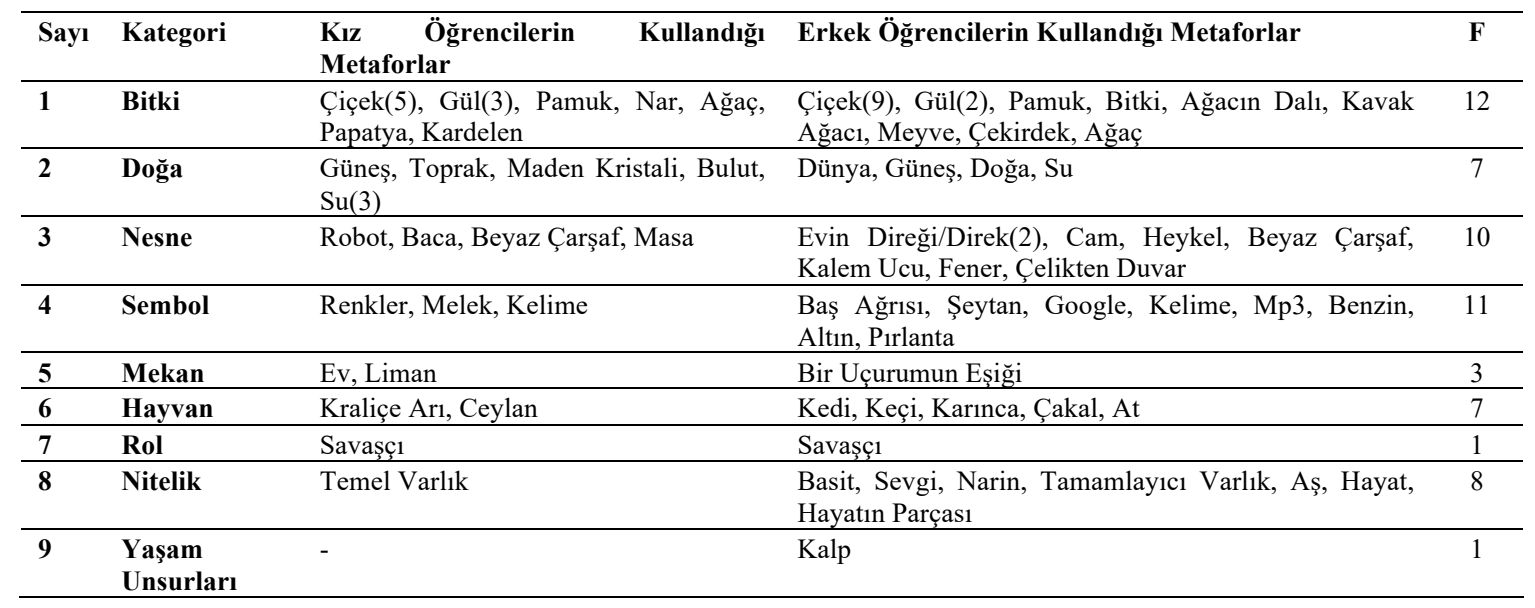

Tablo 2'ye bakıldığında araştırmaya katılan öğrenciler tarafından üretilen metaforlar bitki, doğa, nesne, sembol, mekan, hayvan, rol, nitelik, yaşam unsurları olarak 9 kategoride sınıflanmıştır. Kadın için en fazla bitki (f:12) kategorisinde çiçek (f:14) metaforunu üretmiştir. Sembol (f:11) kategorisinde tekrarlanan metafor yoktur.

Tablo 3. Öğrencilerin Kadın İçin Kullandıkları Metafor Açıklamalarının Kategorileri

\begin{tabular}{|c|c|c|c|c|}
\hline Sayı & Kategoriler & $\begin{array}{l}\text { Kız Öğrencilerin Kullandığı } \\
\text { Metaforlar }\end{array}$ & Erkek Öğrencilerin Kullandığı Metaforlar & $\mathbf{F}$ \\
\hline 1 & $\begin{array}{l}\text { Kırılgan, merhametli, } \\
\text { ezilen ve ilgiye muhtaç }\end{array}$ & $\begin{array}{l}\text { Pamuk, Gül(3), Çiçek(5), } \\
\text { Ceylan, Papatya }\end{array}$ & $\begin{array}{l}\text { Basit, Pamuk, Kedi, Gül(2), Çiçek(9), Sevgi, Cam, } \\
\text { Narin, Bitki, Heykel, Ağacın Dalı, Tamamlayıcı Varlık, } \\
\text { Kavak Ağacı }\end{array}$ & 15 \\
\hline 2 & Hayat kaynağı, değerli & $\begin{array}{l}\text { Su(2), Melek, Maden Kristali, } \\
\text { Kraliçe Arı }\end{array}$ & $\begin{array}{l}\text { Su, Hayat(2), Hayatın Parçası, Çiçek(2), Aş, Doğa, Ağaç, } \\
\text { Kalem Ucu, Kalp, Dünya, Benzin }\end{array}$ & 14 \\
\hline 3 & Akıllı, güçlü, çalışkan & $\begin{array}{l}\text { Kardelen, Masa, Renkler, } \mathrm{Su}, \\
\text { Ağaç, Robot }\end{array}$ & $\begin{array}{l}\text { Bir Uçurumun Eşiği, Altın, Savaşçı, Karınca, Güneş, } \\
\text { Google, Çelikten Duvar, Ağaç }\end{array}$ & 13 \\
\hline 4 & $\begin{array}{l}\text { Paylaşımcı, denge, } \\
\text { ihtiyaç }\end{array}$ & $\begin{array}{l}\text { Güneş, Toprak, Kelime, Baca, } \\
\text { Liman, Ev }\end{array}$ & $\begin{array}{l}\text { Pırlanta, Evin Direği/Direk/Toplumun Direği(3), } \\
\text { Çekirdek, Meyve, Mp3, Fener }\end{array}$ & 12 \\
\hline 6 & İftira atılsa kalır & Beyaz Çarşaf & Beyaz Çarşaf & 1 \\
\hline 7 & $\begin{array}{l}\text { Diğer (Tanımadan } \\
\text { anlaşılmaz, güzel) }\end{array}$ & Nar & At & 2 \\
\hline
\end{tabular}

Tablo 3'e bakıldığında araştırmaya katılan öğrenciler tarafından kadın için üretilen metaforlara ait açıklamaları "kırılgan, merhametli, ezilen ve ilgiye muhtaç", "hayat kaynağı, değerli", "akı1lı, güçlü, çalışkan”, "paylaşımcı, denge, ihtiyaç", "ezen, çok konuşan, sinirli, inatçı", "iftira atılsa kaldığını", "diğer (tanımadan anlaşılmaz, güzel)" olarak 7 kategoride sınıflanmıştır.

Kadının kırılgan, merhametli, ezilen ve ilgiye muhtaç olduğunu vurgulayan metaforlar: Tablo 3'e bakıldığında bu alt kategori ile ilgili toplamda 15 metafor üretilmiştir. 5 metaforu kız, 10 metaforu erkek öğrenci üretmiştir. Kız öğrenciler tarafından, pamuk, gül (3), çiçek (5), ceylan, papatya; Erkek öğrenciler tarafından, basit, pamuk, kedi, gül (2), çiçek (9), sevgi, cam, 
narin, bitki, heykel, ağacın dalı, tamamlayıcı varlık, kavak ağacı metaforları üretilmiştir. Pamuk, gül, çiçek metaforunu kız ve erkek öğrenci üretmiştir. Pamuk metaforu eşit sayıda üretilmiş, çiçek metaforunu en fazla kızlar kullanmıştır. Metaforlara yönelik bazı doğrudan alıntılara aşağıda yer verilmiştir.

"Kadın heykel gibidir. Çünkü kadın zarif ve naziktir. Heykelde zaman ayrintıya gerek vardır, en ufak yanlışta yıkılır ya da bozulur"' (9. Sinıf Erkek 14).

“Kadın kedi gibidir. Çünkü yufka yürekli insandır”' (9. Sinıf Erkek 27).

“Kadın bitki gibidir. Çünkü kadınlar ezilip geçilir, dövülür'” (9. Sinıf Erkek 15).

“Kadın cam gibidir. Çünkü cam gibi hassas kalbi vardır, kırıldı̆̆ı zaman düzelmez'” (9. Sınıf Erkek 21).

“Kadın gül gibidir. Çünkü onu üzersen yapraklarını döker ve solar’” (11. Sınıf Kız 58).

“Kadın çiçek gibidir. Çünkü narindir, kırılgandır”' (11. Sinıf Erkek 60).

“Kadın ceylan gibidir. Çünkü çok kırılgan, narindir'” (12. Sınıf Kız 83).

Kadının hayat kaynağı, değerli olduğunu vurgulayan metaforlar: Tablo 3'e bakıldığında bu alt kategori ile ilgili toplamda 14 metafor üretilmiştir. Kız öğrenciler tarafından, su (2), melek, maden kristali, kraliçe arı; Erkek öğrenciler tarafından, su, hayat (2), hayatın parçası, çiçek (2), aş, doğa, ağaç, kalem ucu, kalp, dünya, benzin metaforları üretilmiştir. Su metaforunu kız ve erkek öğrenci üretmiştir. Metaforlara yönelik bazı doğrudan alıntılara aşağıda yer verilmiştir.

“Kadın su gibidir. Çünkü olmadan hayat olmaz”' (9. Sinıf Erkek 22).

“Kadın hayat gibidir. Çünkü nefesimizi ondan alırız’'(9. Sınıf Erkek 23).

"Kadın melek gibidir. Çünkü dünyanın en önemli kavramıdır. Kadın bu dünyada gereken bir varlıktır. Kadın olmazsa bu dünya hayatı boştur'” (9. Sinıf Kız 8).

"Kadın kraliçe arı gibidir. Çünkü onlar sayesinde bir düzen sağlanır ve onlar sayesinde insanların devamı sağlanır'” (10. Sinıf Kız 33).

"Kadın kalem ucu gibidir. Çünkü kadın olmazsa yani uç olmazsa o evin hayatın bir anlamı kalmaz uçlu kalem olmazsa uç tek başına işe yaramaz. Erkek nasıl kadına ihtiyaç duyuyorsa kadın da erkeğe ihtiyaç duyar"' (11. Sinıf Erkek 62).

Kadının akıllı, güçlü, çalışkan olduğunu vurgulayan metaforlar: Tablo 3'e bakıldığında bu alt kategori ile ilgili toplamda 13 metafor üretilmiştir. Kız öğrenciler tarafından, kardelen, masa, renkler, su, ağaç, robot; Erkek öğrenciler tarafından, bir uçurumun eşiği, altın, savaşçı, karınca, güneş, Google, çelikten duvar, ağaç metaforları üretilmiştir. Ağaç metaforunu kız ve erkek öğrenci eşit sayıda üretmiştir. Metaforlara yönelik bazı doğrudan alıntılara aşağıda yer verilmiştir.

"Kadın kardelen gibidir. Çünkü engelleri delip sonuca ulaşmaya çalışır, soğuğa dayanıklıdır zor koşullarda açar. Kadın da dayanıklıdır” (9. Sinıf Kız 7).

“Kadın savaşçı gibidir. Çünkü kötülüklere karşı çıkandır” (10. Sınıf Erkek 37).

"Kadın bir uçurumun eşiği gibidir. Çünkü bütün riskleri göze alıp hayatın manzarasını seyreder" (10. Sinif Erkek 52).

"Kadın çelikten duvar gibidir. Çünkü aşağılanmaya şiddete karşı dimdik durabilir” (11. Sınıf Erkek 73). 
"Kadın Google gibidir. Çünkü aradı̆̆ın şeylerin çoğunu bulur. Birçok işi yapar. Akıllı varlıklardır” (11. Sinıf Erkek 61).

Kadının paylaşımcı, denge, ihtiyaç olduğunu vurgulayan metaforlar: Tablo 3'e bakıldığında bu alt kategori ile ilgili toplamda 12 metafor üretilmiştir. Kız öğrenciler tarafından, güneş, toprak, kelime, baca, liman, ev; Erkek öğrenciler tarafından, pırlanta, evin direği/direk/toplumun direği (3), çekirdek, meyve, mp3, fener metaforları üretilmiştir. Metaforlara yönelik bazı doğrudan alıntılara aşağıda yer verilmiştir.

“Kadın güneş gibidir. Çünkü kadın parlar, ayı görmeden ışığını paylaşı»” (9. Sınıf Kız 12).

“Kadın toplumun direği gibidir. Çünkü kadın olmazsa toplumda denge olmaz” (9. Sınıf Erkek 26).

“Kadın Fener gibidir. Çünkü karanlıktaki umudumuz”' (11. Sinıf Erkek 69).

"Kadın mp3 gibidir. Çünkü istediğiniz güzel bir şarkıyı ya da hüzün dolu rock, pop vs. gibi sizi rahatlatacak her şeyi onda bulabilirsiniz” (11. Sinıf Erkek 74).

"Kadın baca gibidir. Çünkü dumanı içerdekiler zarar görmesin diye çeker ve dışa aktarır' (11. Sinıf Kı 56).

“Kadın meyve gibidir. Çünkü bulunduğu yeri güzelleştirir” (12. Sınıf Erkek 87).

Kadının ezen, çok konuşan, sinirli, inatçı olduğunu vurgulayan metaforlar: Tablo 3'e bakıldığında bu alt kategori ile ilgili toplamda 4 metafor üretilmiştir. Erkek öğrenciler tarafından, baş ağrısı, şeytan, keçi, çakal metaforları üretilmiştir. Kız öğrenciler bu kategoride metafor üretmemiştir. Metaforlara yönelik bazı doğrudan alıntılara aşağıda yer verilmiştir.

"Kadın baş ăgrısı gibidir. Çünkü günde 10-15 bin kelime konuşup kafamızı sulandırırlar', (9.Sinif Erkek 19).

“Kadın Şeytan Gibidir. Çünkü her zaman insanları kandırıp kötü yola sapmasına neden olur', (9. Sinif Erkek 18).

"Kadın keçi gibidir. Çünkü inatçıdır, siniri aşırı etkilidir, etrafını yıkabilecek potansiyele sahiptir"' (10. Sinif Erkek 53).

“Kadın Çakal gibidir. Çünkü dünyaya erkekleri ezmek için gelmiş’” (12. Sınıf Erkek 85).

Kadına iftira atılsa kaldığını vurgulayan metaforlar: Tablo 3'e bakıldığında bu alt kategori ile ilgili toplamda 1 metafor üretilmiştir. Beyaz çarşaf (2) metaforu üretilmiştir. Metafor üretenler hem kız hem erkek öğrencidir. Metaforlara yönelik bazı doğrudan alıntılara aşağıda yer verilmiştir.

“Kadın Beyaz çarşaf gibidir. Çünkü leke düşse geçmez” (10. Sınıf Kız 34).

“Kadın Beyaz çarşaf gibidir. Çünkü lekelense lekesi çıkmaz” (10. Sınıf Erkek 49).

Diğer: Tablo 3'e bakıldığında bu alt kategoride kadını "tanımadan anlaşılmaz" ile tanımlayan metafor yer almaktadır. Nar metaforu üretilmiştir (1). Metafor üreten kız öğrencidir. Kadını "güzel, etkili" ile tanımlayan 1 metafor da yer almaktadır. Bu alt kategori ile at metaforu üretilmiştir. Metafor üreten erkek öğrencidir. Metaforlara yönelik doğrudan alıntılara aşağıda yer verilmiştir.

"Kadın nara benzer. Çünkü içini görmek gerekir” (10. Sinıf Kız 35).

“Kadın at gibidir. Çünkü ilgi çekici, gizemli, onlara baktığımızda etkileniriz” (12. Sınıf Erkek 89). 


\section{Erkek İçin Üretilen Metaforlara İlişkin Bulgular}

$\mathrm{Bu}$ alt bölümde araştırmaya katılan kız ve erkek öğrencilerin erkeğe ilişkin kullandıkları metaforlar ve açıklamalarının kategorilerine, öğrencilerin ifadelerinden alıntılara yer verilmiştir. Metaforlardan elde edilen kategoriler Tablo 4 'te ve metafor açıklamalarından elde edilen kategoriler Tablo 5 'te yer almaktadır.

Tablo 4. Öğrencilerin Erkek İçin Kullandıkları Metafor ve Kategorileri

\begin{tabular}{llllc}
\hline Sayı & Kategori & $\begin{array}{l}\text { Kız Öğrencilerin Kullandığı } \\
\text { Metaforlar }\end{array}$ & Erkek Öğrencilerin Kullandı̆̆ı Metaforlar & F \\
\hline $\mathbf{1}$ & Nesne & $\begin{array}{l}\text { Çorap, Kapalı Kutu, Yaslanacak Duvar, } \\
\text { Demir, Makine, Direk, Baston, Can } \\
\text { Yeleği, Davul, Gemi, Masa, Odun }\end{array}$ & $\begin{array}{l}\text { Vinç, Davul, Duvar(2), Odun, Boks Torbası, Trafik } \\
\text { Lambası, Cam Bardak, Evin Kolonu, Kapı, Uçlu Kalem, } \\
\text { Korkuluk, Cam, Alışveriş Sepeti, Binanın Dış Duvarı }\end{array}$ & 23 \\
\hline $\mathbf{2}$ & Doğa & $\begin{array}{l}\text { Ay, Güneş, Dağ, Taş, Negatif Atom, } \\
\text { Şimşek, Nehir }\end{array}$ & $\begin{array}{l}\text { Ay, Güneş, Dağ(4), Taş(2), Nehir, Şimşek, Kaya(2), } \\
\text { Toprak, Su }\end{array}$ & 10 \\
\hline $\mathbf{3}$ & Nitelik & $\begin{array}{l}\text { Kahraman, Gelecek, Kanser Hastalığı, } \\
\text { Şizofren }\end{array}$ & Güçlü, Erkek, Kaba, Aşağılık & 8 \\
\hline $\mathbf{4}$ & Sembol & Şifre, Duman, Ateş & Virüs, Kalkan, Sakızlı Lolipop & 6 \\
\hline $\mathbf{5}$ & Hayvan & Aslan, Hayvan & Aslan(6), Köpek, Güvercin, Kedi & 5 \\
\hline $\mathbf{6}$ & Bitki & Ağaç, Çınar(2) & $\begin{array}{l}\text { Diken, Ağaç(3), Kaktüs, Çınar Ağacı(2), Çekirdekte Çıan } \\
\text { Bitki, Yaprak }\end{array}$ & 6 \\
\hline $\mathbf{7}$ & Mekan & Karışık Renkli Çiçek Bahçesi, Yuva & Banka & 3 \\
\hline $\mathbf{8}$ & Rol & - & Koruyucu, Bakan, İş Adamı & 3 \\
\hline $\mathbf{9}$ & Yaşam & - & Atmosfer & 1 \\
\hline
\end{tabular}

Tablo 4'e bakıldığında araştırmaya katılan öğrenciler tarafından üretilen metaforlar nesne, doğa, nitelik, sembol, hayvan, bitki, mekan, rol, yaşam unsurları olarak 9 kategoride sınıflanmıştır. Erkek için en fazla nesne (f:23) kategorisinde metafor üretilmiştir. En fazla aslan (f:7) metaforunu üretmiştir. Erkek için üretilen metaforlarda tekrarlanan metafor oranı düşüktür.

Tablo 5. Öğrencilerin Erkek İçin Kullandıkları Metafor Açıklamalarının Kategorileri

\begin{tabular}{|c|c|c|c|c|}
\hline Sayı & Kategoriler & $\begin{array}{l}\text { Kız Öğrencilerin Kullandığı } \\
\text { Metaforlar }\end{array}$ & Erkek Öğrencilerin Kullandığı Metaforlar & $\mathbf{F}$ \\
\hline 1 & $\begin{array}{l}\text { Güçlü, Otoriter, } \\
\text { Koruyan, Azimli }\end{array}$ & $\begin{array}{l}\text { Dağ, Yaslanılacak Duvar, } \\
\text { Makine, Kahraman, Yuva, } \\
\text { Direk, Baston, Can Yeleği }\end{array}$ & $\begin{array}{l}\text { Güçlü, Aslan(5), Vinç, Odun, Koruyucu, Dağ(4), } \\
\text { Kaba, Trafik Lambası, Ağaç, Kalkan, Kaktüs, Çınar } \\
\text { Ağacı(2), Kapı, Duvar/Bina Duvarı(2), Atmosfer, } \\
\text { Yaprak, Bakan }\end{array}$ & 23 \\
\hline 2 & $\begin{array}{l}\text { Şiddet Uygulayan, } \\
\text { Merhametsiz, Uyumsuz }\end{array}$ & $\begin{array}{l}\text { Aslan, Davul, Güneş, Demir, } \\
\text { Duman, Şimşek, Hayvan }\end{array}$ & $\begin{array}{l}\text { Aslan, Davul, Virüs, Köpek, Taş(2), Kaya(2), } \\
\text { Aşağılık, Cam }\end{array}$ & 13 \\
\hline 3 & $\begin{array}{l}\text { Narin Ve Çetin, İlgi } \\
\text { İsteyen }\end{array}$ & Çorap, Taş & Kedi & 3 \\
\hline 4 & $\begin{array}{l}\text { Kaba, Duygularını } \\
\text { Yansitmayan }\end{array}$ & $\begin{array}{l}\text { Kapalı Kutu, Kanser } \\
\text { Hastalığı, Negatif Atom, } \\
\text { Şifre }\end{array}$ & Diken, Duvar, Sakızlı Lolipop & 7 \\
\hline 5 & $\begin{array}{l}\text { Muhtaç, Yönlendirilen, } \\
\text { Sorumsuz }\end{array}$ & $\begin{array}{l}\text { Ağaç, Ay, Karışık Renkli } \\
\text { Çiçek Bahçesi, Nehir, } \\
\text { Şizofren, Masa }\end{array}$ & $\begin{array}{l}\text { Araba, Ağaç, Uçlu Kalem, Alışveriş Sepeti, } \\
\text { Çekirdekte Çıkan Bitki, Odun }\end{array}$ & 11 \\
\hline 6 & Evine Karşı Sorumlu & Gemi, Ateş & $\begin{array}{l}\text { Güvercin, Cam Bardak, Evin Kolonu, Banka, İş } \\
\text { Adamı, Korkuluk, Boks Torbası }\end{array}$ & 9 \\
\hline 7 & $\begin{array}{l}\text { Hayal Kurulan, } \\
\text { Doyulamayan }\end{array}$ & Gelecek & $\mathrm{Su}$ & 2 \\
\hline 8 & Diğer(Yaşam Kaynağı) & - & Toprak & 1 \\
\hline
\end{tabular}

Tablo 5'e bakıldığında araştırmaya katılan öğrenciler tarafından erkek için üretilen metaforlara ait açıklamaları "güçlü, otoriter, koruyan, azimli", "şiddet uygulayan, merhametsiz, uyumsuz", "narin ve çetin, ilgi isteyen", "kaba, duygularını yansıtmayan", "muhtaç, yönlendirilen, sorumsuz", "evine karşı sorumlu", "hayal kurulan, doyulamayan", "diğer(yaşam kaynağı)" olarak 8 kategoride sınıflanmıştır.

Erkeğin güçlü, otoriter, koruyan, azimli olduğunu vurgulayan metaforlar: Tablo 5'e bakıldığında bu alt kategori ile ilgili toplamda 23 metafor üretilmiştir. Kız öğrenciler, dağ, 
yaslanılacak duvar, makine, kahraman, yuva, direk, baston, can yeleği metaforlarını üretmiştir. Erkek öğrenciler, güçlü, aslan (5), vinç, odun, koruyucu, dağ (4), kaba, trafik lambası, ağaç, kalkan, kaktüs, çınar ağacı (2), kapı, duvar/bina duvarı (2), atmosfer, yaprak, bakan metaforlarını üretmiştir. Dağ metaforunu hem erkek hem kız öğrenci üretmiştir. Dağ metaforunun erkeklerde tekrarlanma sıklığ 4, kızlarda 1'dir. Metaforlara yönelik bazı doğrudan alıntılara aşağıda yer verilmiştir.

"Erkek yaslanılacak duvar gibidir. Çünkü kadınları hemcinsinden korur, korkuyu yenmesine yardımcı olur”' (9. Sinıf Kız 7).

"Erkek kahraman gibidir. Çünkü bu dünya hayatında sahiplenme duygusunu taşır. Güçlüdür, kadını korur, gözetir. Sahiplenir kendisine emanetmiş gibi bakar’” (9. Sınıf Kız 8).

“Erkek vinç gibidir. Çünkü hangi yükü alsa üstesinden gelir ve asla pes etmez. Özgüvensiz kalmaz söylediği şeyin ardında durur”' (9. Sinıf Erkek 23).

"Erkek çınar ă̆acı gibidir. Çünkü kolay kolay devrilmez” (10. Sinıf Erkek 38).

“Erkek kaktüs gibidir. Çünkü her zorlukta hayatta kalabilir”' (10. Sinıf Erkek 43).

“Erkek bakan gibidir. Çünkü evin direğidir. Evin hakimiyeti elindedir”' (10. Sinıf Erkek 48).

“Erkek can yeleği gibidir. Çünkü gerektiği zaman seni korur”' (11.Sinıf Klz 54).

“Erkek aslan gibidir. Çünkü erkek gücüyle ön plana çıkar, en belirgin özelliği gücüdür”' (11. Sinıf Erkek 71).

"Erkek duvar gibidir. Çünkü erkeğe sırtını yaslayan içinde yere düşme korkusu bulundurmaz seni korur”' (11. Sinif Erkek 74).

"Erkek atmosfer gibidir. Çünkü dünyadaki canlıların dış etmenlerden korunmasını ve onların rahat yaşamaları için dünyayı sarar”' (12. Sinıf Erkek 92).

Erkeğin şiddet uygulayan, merhametsiz, uyumsuz olduğunu vurgulayan metaforlar: Tablo 5'e bakıldığında bu alt kategori ile ilgili toplamda 13 metafor üretilmiştir. Kız öğrenciler, aslan, davul, güneş, demir, duman, şimşek, hayvan; erkek öğrenciler, aslan, davul, virüs, köpek, taş (2), kaya (2), aşağılık, cam metaforlarını üretmiştir. Aslan ve davul metaforlarını hem erkek hem kız öğrenci eşit sayıda üretmiştir. Metaforlara yönelik bazı doğrudan alıntılara aşağıda yer verilmiştir.

“Erkek hayvan gibidir. Çünkü nazik değildir, kadına şiddet uygular, güçlüdür’’(9. Sınıf Kız 2).

"Erkek virüs gibidir. Çünkü erkek her şey onunmuş gibi sanıp davranır toplumun dengesini bozar” (9. Sinif Erkek 26).

"Erkek köpek gibidir. Çünkü erkek vahşi hareketler sunar kadını haklı çıkarmaz şiddete maruz birakır”' (9. Sinif Erkek 27).

"Erkek duman gibidir. Çünkü içerde de kalsa zarar dışarıda da kalsa zarar. Kadının suçu yok yani'”(11. Sinıf Kiz 56).

"Erkek aşağılık gibidir. Çünkü kadınlara ă̆zında şiddet eden her türlü küfrü bulunduran insandır'”(11. Sinıf Erkek 65).

“Erkek şimşek gibidir. Çünkü birden parlar nasıl olduğu anlaşılmaz”’ (12. Sinıf Kız 78).

Erkeğin narin ve çetin, ilgi isteyen olduğunu vurgulayan metaforlar: Tablo 5'e bakıldığında bu alt kategori ile ilgili toplamda 3 metafor üretilmiştir. Kız öğrenciler, çorap, taş; erkek öğrenci kedi metaforlarını üretmiştir. Metaforlara yönelik bazı doğrudan alıntılara aşağıda yer verilmiştir. 
“Erkek kedi gibidir. Çünkü ilgi isteyen ve herkesin ilgisini çekmek için uğraşır'” (10. Sınıf Erkek 49).

"Erkek taş gibidir. Çünkü kadınlar gibi cesaretli değiller. Dıştan güçlü dururlar, bir balyoz yeter kırmaya”" (11. Sinif Kiz 55).

Erkeğin kaba, duygularını yansıtmayan olduğunu vurgulayan metaforlar: Tablo 5'e bakıldığında bu alt kategori ile ilgili toplamda 7 metafor üretilmiştir. Kız öğrenciler, kapalı kutu, kanser hastalığı, negatif atom, şifre; erkek öğrenciler diken, duvar, sakızlı lolipop metaforlarını üretmiştir. Metaforlara yönelik bazı doğrudan alıntılara aşağıda yer verilmiştir.

"Erkek şifre gibidir. Çünkü onu çözemeden anlaman kolay olmaz. Sen onu çözemezsen o sana karşı hiçbir kapıyı açmaz”’ (9. Sinıf Kız 1).

“Erkek kapalı kutu gibidir. Çünkü hiçbir şey söylemez”’ (9. Sinıf Kız 13).

"Erkek diken gibidir. Çünkü toplumda biraz daha kabadır. Ince bir özellikleri yoktur, söylediğiniz birkaç cümle ile kırılan bir varlık değildir"’ (9. Sinıf Erkek 25).

“Erkek negatif atom gibidir. Çünkü duygularını dışa yansıtmaz”’ (11. Sinıf kız 67).

“Erkek sakızlı lolipop gibidir. Çünkü dıştan sert duygusuz içten hassas kırılgan'” (11. Sinıf Erkek 69).

Erkeğin muhtaç, yönlendirilen, sorumsuz olduğunu vurgulayan metaforlar: Tablo 5'e bakıldığında bu alt kategori ile ilgili toplamda 11 metafor üretilmiştir. Kız öğrenciler, ağaç, ay, karışık renkli çiçek bahçesi, nehir, şizofren, masa; erkek öğrenciler, araba, ağaç, uçlu kalem, alışveriş sepeti, çekirdekte çıkan bitki, odun metaforlarını üretmiştir. Ağaç metaforu hem kız hem erkek öğrenci tarafından eşit sayıda üretilmiştir. Metaforlara yönelik bazı doğrudan alıntılara aşağıda yer verilmiştir.

“Erkek karışık renkli çiçek bahçesi gibidir. Çünkü karışık beyinlidir ne yapacă̆ını bilmez'” (9. Sinif Klz 5).

“Erkek odun gibidir. Çünkü kafası hep aynı şeye çalışır bir şey söylersen kafasına girmez”' (12. Sinıf Kız 81).

“Erkek şizofren gibidir. Çünkü nerde nasıl davranacă̆ı belli olmuyor” (12. Sınıf Kız 79).

"Erkek alışveriş sepeti gibidir. Çünkü kadınlara hizmet etmekten bakıcllık yapmaktan kendilerine zaman ayıramaz. Sevgili eşleri tarafindan alışveriş sepeti gibi kullanılır" (12. Sınıf Erkek 85).

Erkeğin evine karşı sorumlu olduğunu vurgulayan metaforlar: Tablo 5'e bakıldığında bu alt kategori ile ilgili toplamda 9 metafor üretilmiştir. Kı öğrenciler, gemi, ateş; erkek öğrenciler, güvercin, cam bardak, evin kolonu, banka, iş adamı-köle, korkuluk, boks torbası metaforlarını üretmiştir. Metaforlara yönelik bazı doğrudan alıntılara aşağıda yer verilmiştir.

“Erkek boks torbası gibidir. Çünkü kendine önem vermez”' (9.Sinıf Erkek 16).

"Erkek güvercin gibidir. Çünkü gider çalışır buğday yer gelir yavrusunun ağzına boşaltır. Erkekte bu çabayla çalışır’” (10. Sinıf Erkek 45).

"Erkek banka gibidir. Çünkü Erkeklerden para beklenir. Insan istediği zaman para alabilir ya da çekebilir. Onun için erkek hep çalışmall ya da para kazanmalı”' (11. Sinıf Erkek 61).

“Erkek İ̧s adamı(Köle). Çünkü işe girip aile parasını kazanır” (11.sınıf Erkek 64).

“Erkek korkuluk gibidir. Çünkü evini ailesini korur”' (11.Sinıf Erkek 68). 
Erkeğin hayal kurulan, doyulamayan olduğunu vurgulayan metaforlar: Tablo 5'e bakıldığında bu alt kategori ile ilgili toplamda 2 metafor üretilmiştir. Kız öğrenci, gelecek, erkek öğrenci su metaforunu üretmiştir. Metaforlara yönelik bazı doğrudan alıntılara aşağıda yer verilmiştir.

“Erkek gelecek gibidir. Çünkü hayali kurulur”' (9.Sınıf Kız 3).

“Erkek su gibidir. Çünkü saftır, temiz içi dışı aynı iç iç doymazsın” (12.sınıf Erkek 89).

Diğer: Tablo 5'e bakıldığında bu alt kategoride erkeği "yaşam kaynağı" ile tanımlayan metafor yer almaktadır. $\mathrm{Bu}$ alt kategori ile ilgili toplamda 1 metafor üretilmiştir. Toprak metaforu üretilmiştir. Metafor üreten erkek öğrencidir. Metafora yönelik doğrudan alıntıya aşağıda yer verilmiştir.

\section{"Erkek toprak gibidir. Çünkü çiçeğin evi veya yaşam kaynă̆l gibidir"' (11.sinıf Erkek 75).}

\section{Kadın Resimlerine İlişkin Bulgular}

$\mathrm{Bu}$ alt bölümde araştırmaya katılan öğrencilerin çizdikleri kadın resimlerine yazdıkları açıklamaları Tablo 6'da cinsiyet değişkeni ile birlikte kategori halinde verilmiştir. Ayrıca öğrencilerin çizimlerinden alıntı yapılmıştır.

Tablo 6. Öğrencilerin Çizdikleri Kadın Resimlerine Yazdıkları Açıklamaların Kategorilerine İlişkin Niteleme Sıklıkları

\begin{tabular}{llccc}
\hline Sayı & Kadın & $\begin{array}{c}\text { Kız } \\
\text { Öğrenci }\end{array}$ & $\begin{array}{c}\text { Erkek } \\
\text { Öğrenci }\end{array}$ & Toplam \\
\hline $\mathbf{1}$ & Özgür, umursamaz, özsaygısı olan & 11 & 6 & 17 \\
\hline $\mathbf{2}$ & Her işi yapabilen, güçlü, cesaretli & 13 & 3 & 16 \\
\hline $\mathbf{3}$ & Ev işleri, çocuk bakımı, bahçe işleri & - & 15 & 15 \\
\hline $\mathbf{4}$ & Sevgi, iyi, narin, özlem duyan, temiz & 4 & 13 & 17 \\
\hline $\mathbf{5}$ & Kitap okuyan, okula giden & 1 & 2 & 3 \\
\hline $\mathbf{6}$ & Gezen, alışveriş yapan, parayı seven & - & 5 & 5 \\
\hline $\mathbf{7}$ & Tedirgin, mutsuz, terk eden, yalnız, fakir, dayatılan & 2 & 10 & 12 \\
\hline $\mathbf{8}$ & işleri yapan, geçmişini değerlendiren & & & 1 \\
\hline $\mathbf{9}$ & Gügelli & 1 & - & 18 \\
\hline
\end{tabular}

Tablo 6'da verilen bilgilere bakıldığında, kadınların ‘özgür, umursamaz, özsaygısı olan' olarak niteleme sıklığ 1 kız öğrencilerde 11, erkek öğrencilerde 6'dır. 'Her işi yapabilen, güçlü, cesaretli' olarak niteleme sıklığ 1 kız öğrencilerde 13, erkek öğrencilerde 3'tür. K1z öğrencilerinin resimlerinde kadını 'ev işleri, çocuk bakımı, bahçe işleri' ve 'gezen, alışveriş yapan, parayı seven' olarak niteleyen veriye rastlanılmamıştır. Erkek öğrenciler ise kadını 'ev işleri, çocuk bakımı, bahçe işleri' ile uğraşan olarak niteleme sıklığ 15 tir. 'Gezen, alışveriş yapan, parayı seven' olarak niteleme sıklığı 5'tir. 'Sevgi, iyi, narin, özlem duyan, temiz' kategorisine ait kız öğrencilerin resimlerindeki veri sayısı 4, erkek öğrencilerde 13'tür. Erkek öğrencilerde sınıf düzey yükseldikçe azalma göstermektedir. 'Kitap okuyan, okula giden' kategorisinde kız öğrencilerin resimlerindeki veri sayısı 1, erkek öğrencilerde 2'dir. 'Tedirgin, mutsuz, terk eden, yalnız, fakir, dayatılan işleri yapan, geçmişini değerlendiren' kategorisine ait k1z öğrencilerin resimlerindeki veri sayısı 2, erkek öğrencilerde 10'dur. 'Engelli' kategorisine erkek öğrencilerin resimlerinde veriye rastlanılmamıştır. Kız öğrencilerde ise 1 'dir. 'Güzel, açık giyim' kategorisine ait kız öğrencilerin resimlerindeki veri sayısı 10, erkek öğrencilerde 8'dir. 


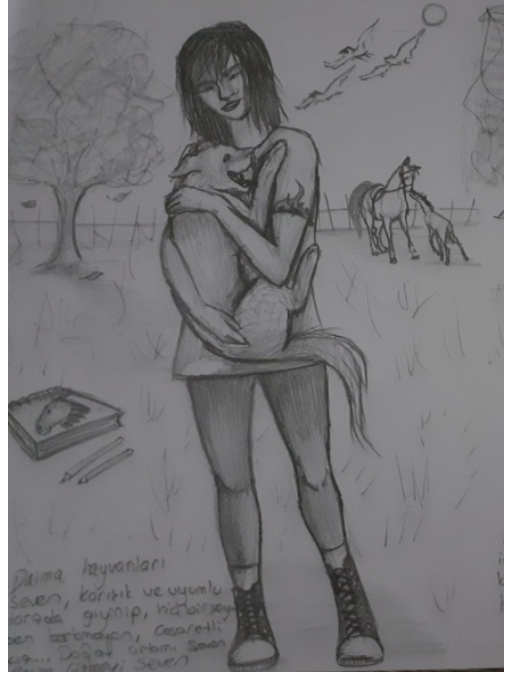

Resim 1.(9. Sinıf Kız, 3)

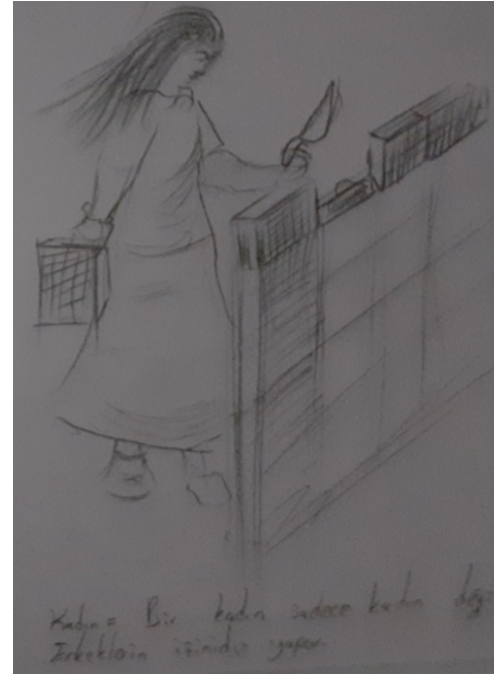

Resim 2.(11. Sinıf Erkek, 68)

Resim 1'de “kadın hayat doludur, kadın özgürdür', Resim 2'de 'bir kadın sadece kadın değildir erkeklerin işini de yapar' ' ifadelerini yazmışlardır.

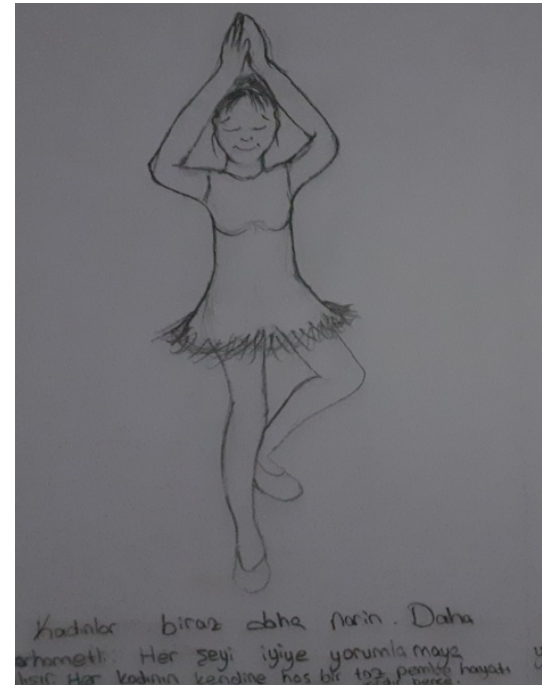

Resim 3. (12 Sinıf Kız, 77)

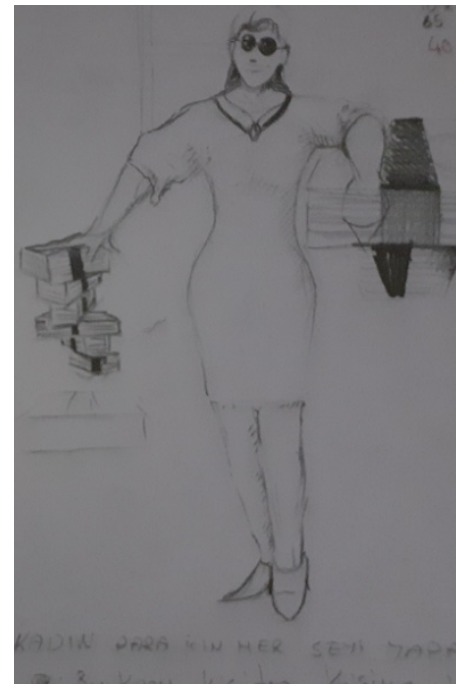

Resim 4. (10. Sinıf Erkek, 40)

Resim 3'te "kadınlar biraz daha narin, daha merhametli, her şeyi iyiye yorumlama çalışır, her kadının kendine has bir toz pembe hayatı vardır bence", Resim 4'te "kadın para için her şeyi yapar' 'ifadelerini yazmışlardır.

\section{Erkek Resimlerine İlişkin Bulgular}

$\mathrm{Bu}$ alt bölümde araştırma katılan öğrencilerin çizdikleri erkek resimlerine yazdıkları açıklamaları Tablo 7'de cinsiyet değişkeni ile birlikte kategori halinde verilmiştir. Ayrıca ögrencilerin çizimlerinden alıntı yapılmıştır. 
Tablo 7. Öğrencilerin Çizdikleri Erkek Resimlerine Yazdıkları Açıklamaların Kategorilerine İlişkin Niteleme Sıklıkları

\begin{tabular}{llccc}
\hline Sayı & Erkek & $\begin{array}{c}\text { Kız } \\
\text { ögrenci }\end{array}$ & $\begin{array}{c}\text { Erkek } \\
\text { Öğrenci }\end{array}$ & Toplam \\
\hline $\mathbf{1}$ & Özgür, özgüvenli & 3 & 1 & 4 \\
\hline $\mathbf{2}$ & Güçlü, koruyan, kahraman, otoriter & 1 & 10 & 11 \\
\hline $\mathbf{3}$ & Çalışan, Para kazanan & 5 & 15 & 20 \\
\hline $\mathbf{4}$ & Ev işi yapan & 1 & - & 1 \\
\hline $\mathbf{5}$ & $\begin{array}{l}\text { Dalgın, olgun olmayan, bilgisiz, çaresiz, terk edilmiş, kolaya } \\
\text { kaçan, parası olmayan }\end{array}$ & 3 & 9 & 12 \\
\hline $\mathbf{6}$ & Ciddi, kaba & 2 & 4 & 6 \\
\hline $\mathbf{7}$ & $\begin{array}{l}\text { Dürüst, saygılı, kadına değer veren, dikkatli, başarılı, } \\
\text { şükreden }\end{array}$ & 10 & 8 & 18 \\
\hline $\mathbf{8}$ & $\begin{array}{l}\text { Kırıp döken, acımasız, kötü, parasına güvenen, boş vakit } \\
\text { geçiren, asi }\end{array}$ & 6 & 9 & 15 \\
\hline $\mathbf{9}$ & Sigara-alkol kullanan & 2 & 3 & 5 \\
\hline $\mathbf{1 0}$ & Açık giyim, modaya uygun giyim, bakımına önem veren & 4 & 5 & 9 \\
\hline $\mathbf{1 1}$ & Engelli & - & 2 & 2 \\
\hline $\mathbf{1 2}$ & Kitap okuyan okula giden & 1 & 3 & 4 \\
\hline
\end{tabular}

Tablo 7'de verilen bilgilere bakıldığında, erkeklerin 'özgür, özgüvenli' niteleme sıklı̆̆ı kız öğrencilerde 3, erkek öğrencilerde 1'dir. 'Güçlü, koruyan, kahraman, otoriter' kategorisine ait kız öğrencilerin resimlerindeki veri sayısı 1, erkek öğrencilerde 10'dur. 'Çalışan, para kazanan' kategorisine ait kı öğrencilerin resimlerindeki veri sayısı 5, erkek öğrencilerde 15'tir. 'Ev işi yapan' kategorisine ait kız öğrencilerin resimlerindeki veri sayısı 1 iken erkek öğrenciler veri üretmemiştir. 'Dalgın, olgun olmayan, bilgisiz, çaresiz, terk edilmiş, kolaya kaçan, parası olmayan' kategorisine ait kız öğrencilerin resimlerindeki veri sayısı 3, erkek öğrencilerde 9'tur. 'Ciddi, kaba' kategorisine ait kız öğrencilerin resimlerindeki veri sayısı 3, erkek öğrencilerde 9'tur. 'Dürüst, saygılı, kadına değer veren, dikkatli, başarılı, şükreden' kategorisine ait kız öğrencilerin resimlerindeki veri sayısı 10, erkek öğrencilerin 8'dir. 'Kırıp döken, acımasız, kötü, parasına güvenen, boş vakit geçiren, asi' kategorisine ait kız öğrencilerin resimlerindeki veri sayısı 6, erkek öğrencilerin ise 9'tur. 'Sigara-alkol kullanan' kategorisine ait k1z öğrencilerin resimlerindeki veri sayısı 2, erkek öğrencilerde 3'tür. 'Açık giyim, modaya uygun giyim, bakımına önem veren' kategorisine ait kız öğrencilerin resimlerindeki veri sayısı 4, erkek öğrencilerin ise 5'tir. 'Engelli' kategorisine ait kız öğrencilerin resimlerindeki veri yokken, erkek öğrencilerde 2'dir. 'Kitap okuyan okula giden' kategorisine ait kız öğrencilerin resimlerindeki veri sayısı 1 , erkek öğrencilerde 3 'tür. 


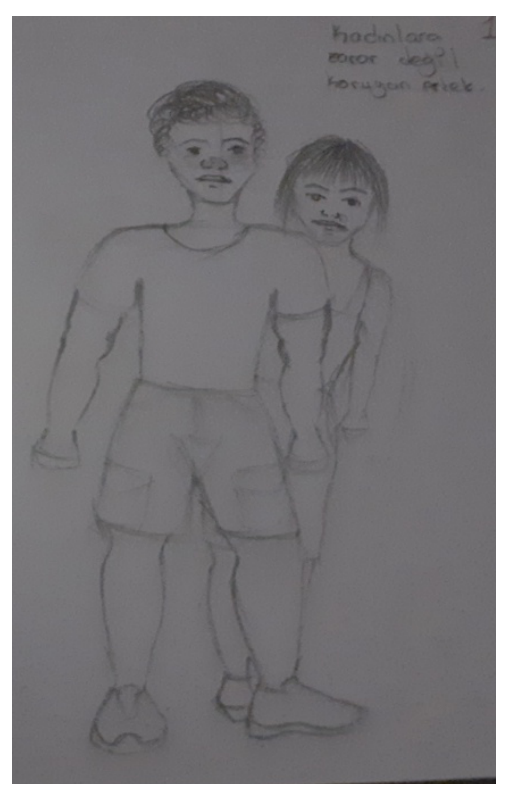

Resim 5. (9. Sinıf Erkek, 1)

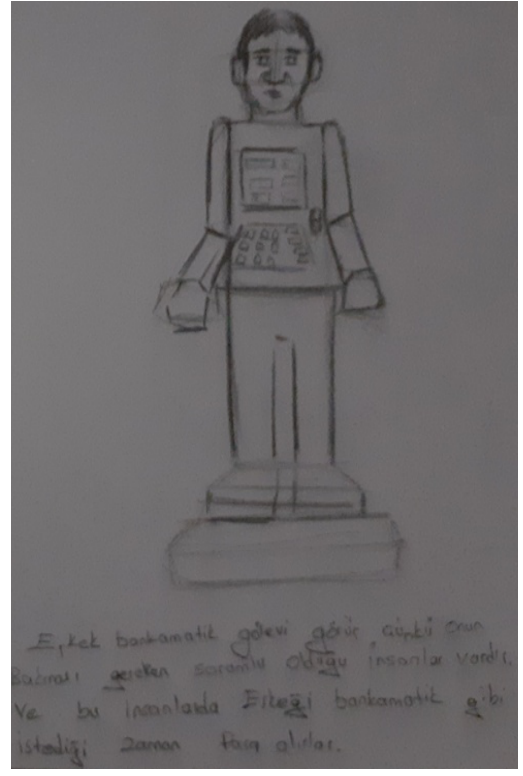

Resim 6. (11. Sinıf Erkek, 61)

Resim 5'te 'Bir erkek ailesi için, çocukları için çalışıp durur, ailesi için yapması gerekeni yapar" Resim 6'da 'kadınlara zarar değil, koruyan erkek”' ifadelerini yazmışlardır.

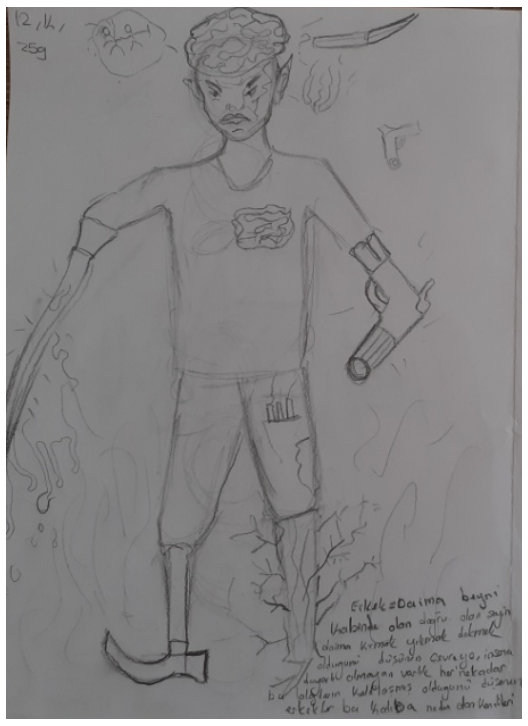

Resim 7.(12. Sinıf K1z, 80)

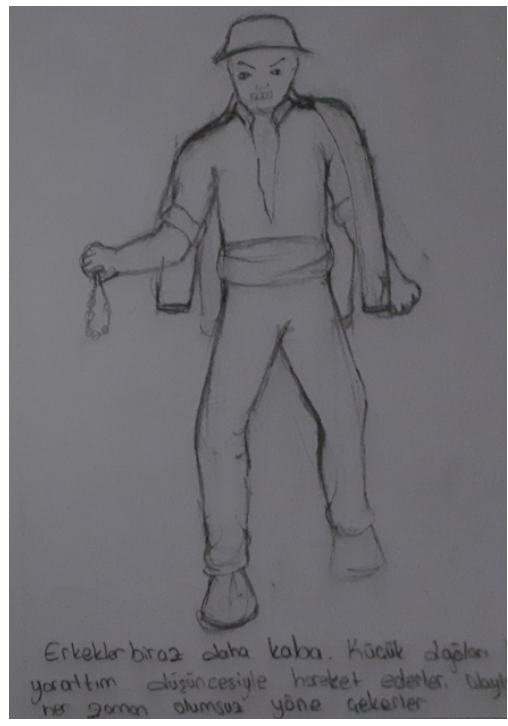

Resim 8. (12. Sinıf Kız, 78)

Resim 7'de 'erkek daima beyni kalbinde olan, doğru olan şeyin daima kırmak, ylkmak, dökmek olduğunu düşünen çevreye, insana duyarlı olmayan varlık her ne kadar bu algıların kalıplaşmış olduğunu düşünen erkekler bu kalıba neden olan kendileri'” Resim 8'de 'erkekler biraz daha kaba, küçük dağları ben yarattım düşüncesiyle hareket ederler, olayları her zaman olumsuz yöne çekerler"' ifadelerini yazmışlardır.

\section{Tartışma}

Kız öğrenciler kadın için 25 metafor üretmiştir. Kadını açıklarken ağırlıklı olarak bitki kategorisindeki metaforları kullandığı görülmüştür. Kız öğrencilerde en çok frekansı alan metaforlar, çiçek (5), gül (3) dür. Bu bulgu Sözer ve Özkan (2014) tarafindan yapılan en çok üretilen metaforların çiçek ve gül bulgusuyla örtüşmektedir. Aslan (2015) tarafından yapılan 
çalışmanın kadınlar için en çok kullanan metafor çiçektir bulgusuyla örtüşmektedir. Yeşilkayalı vd. (2019) tarafından yapılan çalışmanın kadın için en fazla "çiçek" metaforunun kullanılmış olduğu bulgusuyla örtüşmektedir. Kadın için kız öğrencilerde bitki, doğa, nesne, sembol, mekan, hayvan, rol, nitelik metafor kategorileri görülmüştür. Savaşçı metaforunu her iki cinsiyette üretmiştir. Kız öğrenciler hayvan kategorisinde kraliçe arı, ceylan metaforlarını üretmiştir.

Erkek için üretilen metafor sayısı kız öğrencilerde 34'tür. Erkeğe üretilen metaforlar daha fazla çeşitlilik göstermektedir. Kız öğrencilerde en çok frekansı alan metafor çınar (2) dır. Kız öğrencilerin erkeği açıklarken ağırlıklı olarak nesne kategorisindeki metaforları kullandığı görülmüş̦tür. Kız öğrenciler hayvan kategorisinde aslan, hayvan metaforlarını üretmiştir. Erkeği "şiddet uygulayan, merhametsiz, vahşi, uyumsuz, sinirli" ile tanımlayan kız öğrenciler, aslan, davul, güneş, demir, duman, şimşek, hayvan metaforlarını üretmiştir. Erkeği "narin ve çetin, ilgi isteyen" ile tanımlayan kız öğrenciler, çorap, taş metaforlarını üretmiştir. Erkeği "muhtaç, yönlendirilen, sorumsuz" ile tanımlayan kız öğrenciler, ağaç, ay, karışık renkli çiçek bahçesi, nehir, şizofren, masa metaforlarını üretmiştir. "Kırılgan olmayan, kaba" ile tanımlayan kız öğrenciler, kapalı kutu, kanser hastalığı, negatif atom, şifre metaforlarını üretmiştir.

Kız öğrenciler kadını "güzel, etkili” olarak nitelendiren metaforlar üretmemiştir. Fakat çizimlerinde kadını 'güzel, açık giyim' olarak nitelendiren veri sayısı 10'dur. Metafor ve resimlerde kadını akıllı, güçlü, çalışkan, her işi yapabilen ve narin, ilgi isteyen, kırılgan, merhametli olarak nitelendirilmiştir. Topuz ve Erkanlı (2016) tarafından yapılan çalışmanın kadın kırılgan, ilgiye ve bakıma muhtaç, anlaşılması zor, çalışkan ve sorumluluk sahibi ve yaşamın devamlılığını sağlayan bulgularıyla örtüşmektedir. Aslan (2015) tarafından yapılan çalışmanın kadınların hassas, ilgiye muhtaç olarak tanımlanan bulgusuyla örtüşmektedir. Yeşilkayalı vd. (2019) tarafindan yapılan çalışmanın "kadını duygusal, merhametli, kırılgan ve sevgiye muhtaç olarak tanımlayan metaforlar" üretilmiştir bulgusuyla örtüşmektedir. Çalışmada metaforlar da değil sadece resimlerde kadın özgür, özgüvenli, öz saygısı yüksek olarak nitelendirilmiştir. Çalışmanın kadın, kırılgan, özgür, ezilen, güzel, çalışkan, sorumluluk sahibi bulgularıyla Uğurlu ve Türkoğlu (2016) tarafından yapılan çalışmanın bekar kadın, kırılgan, özgürlüğüne düşkün, güzel, baskılanan; evli kadın, çalışkan, ev hanımı, ailesine bağlı bulguları örtüşmektedir.

Erkek öğrenciler kadın için 42 metafor üretmiştir. Kadını açıklarken ağırlıklı olarak bitki kategorisindeki metaforları kullandıkları görülmüştür. En çok frekansı alan metaforlar erkek öğrencilerde, çiçek (9), güldür(2). Bu bulgu Sözer ve Özkan (2014) tarafından yapılan en çok üretilen metaforların çiçek ve gül bulgusuyla örtüşmektedir. Aslan (2015) tarafından yapılan çalışmanın kadınlar için en çok kullanan metafor çiçektir bulgusuyla örtüşmektedir. Yeşilkayalı vd. (2019) tarafından yapılan çalışmanın kadın için en fazla "çiçek" metaforunun kullanılmış olduğu bulgusuyla örtüşmektedir. Kadın için erkek öğrencilerde bitki, doğa, nesne, sembol, mekan, hayvan, rol, nitelik, yaşam unsurları metafor kategorileri görülmüştür. Hayvan kategorisinde erkek öğrenciler kedi, keçi, karınca, çakal, at metaforlarını üretmiştir. Erkek için üretilen metafor sayısı erkek öğrencilerde 46' dır. Erkeğe üretilen metaforlar daha fazla çeşitlilik göstermektedir. Erkek öğrencilerde en çok frekansı alan metaforlar aslan (6), dağdır (4). Erkek öğrencilerin erkek ifadesini açıklarken ağırlıklı olarak nesne kategorisindeki metaforları kullandıkları görülmüştür. Erkek öğrenciler hayvan kategorisinde aslan, köpek, güvercin, kedi metaforlarını üretmiştir. Erkeği "şiddet uygulayan, merhametsiz, vahşi, uyumsuz, sinirli" ile tanımlayan erkek öğrenciler, aslan, davul, virüs, köpek, taş (2), kaya (2), aşağılık, cam metaforlarını üretmiştir. Olumsuz özelliklerle erkeği nitelendirilmesi kız öğrencilere göre daha fazla erkek öğrenci tarafindan yapılmıştır. Erkeği "narin ve çetin, ilgi isteyen" ile tanımlayan erkek öğrenci kedi metaforlarını üretmişlerdir. Erkeği "muhtaç, yönlendirilen, sorumsuz" ile tanımlayan erkek öğrenciler, araba, ağaç, uçlu kalem, alışveriş sepeti, çekirdekte çıkan bitki, 
odun metaforunu üretmiştir. Erkeği "kırılgan olmayan, kaba" ile tanımlayan erkek öğrenciler diken, duvar, sakızlı lolipop metaforlarını üretmiştir.

Metafor ve resimlerde erkek, 'Kırıp döken, merhametsiz, acımasız, eziyet eden, kötü, parasına güvenen, boş vakit geçiren, asi'" "şiddet uygulayan, merhametsiz, vahşi, uyumsuz, sinirli" 'ciddi, kaba' olarak nitelendirilmiştir. Aslan (2015) tarafından yapılan çalışmada erkekler “erkekleri kaba, sert ve duygusuz” olarak nitelendirmesi bulgusuyla örtüşmektedir. Çalışmanın erkek özgür, güçlü, sert, kaba, ailesi, çocukları için çalışan bulgularıyla, Sakallı Uğurlu ve Türkoğlu (2016) tarafından yapılan çalışmada katılımcıların "erkekleri güçlü, özgür, sorumluluk sahibi, baba, aile reisi, sert" olarak nitelendirmesi bulgularıly örtüşmektedir. Metafor ve resimlerde erkek 'Güçlü, koruyan, kahraman, otoriter' olarak nitelendirilmiştir. Güder (2014) tarafından yapılan çalışmanın erkeklerin güçlü, ağlamayan olarak tanımlanan bulgusuyla örtüşmektedir. Resim çizimlerinde kız öğrenciler kadını özgür, özsaygısı yüksek, yetenekli, güçlü; erkeği dürüst, saygılı, kadına değer veren olarak nitelendirmiştir. Erkek öğrenciler kadını ev işleri yapan, çocuk bakımıyla ilgilenen, narin, duygusal; erkeği güçlü, koruyan, kahraman, çalışan, para kazanan olarak nitelendirmiştir. Van ilinin doğum oranı halen oldukça yüksek düzeydedir (Başıüyük, 2005). "Van kent merkezindeki aşiret yapılarının geçmişte olduğu kadar sosyal, ekonomik ve kültürel ilişkilerde etkin olmasalar da- hem akrabalık bağlarının korunmasında hem de erken yaşta evliliklerin devamlılığını sağlamada hala etkili oldukları söylenebilir" (Tuğrul Gezer, 2018). Bu durum ilin toplumsal yapısının bireylerin cinsiyet rollerini algılama biçimleri üzerinde etkili olduğunu düşündürmektedir. Çalışmanın bu bulguları, Türkmen ve Alptekin (2020) tarafından yapılan çalışmanın erkek öğrencilerin kız öğrencilere nazaran toplumsal cinsiyet eşitliği konusunda daha geleneksel görüşlere sahip olduğu bulgusuyla örtüşmektedir. Çalışan, para kazanan, ailesi ve çocukları için çalışan' olarak ta nitelendirilmiş. Metaforlardan farklı olarak erkeği dalgın, olgun olmayan, bilgisiz, çaresiz, terk edilmiş, kolaya kaçan, parası olmayan', sigara-alkol kullanan' 'açık giyim, fiziksel görüntü, modaya uygun tarz giyim bakımına önem veren' engelli' kitap okuyan okula giden olarak' niteleyen veriler resimlerde yer almıştır. Resimlerde 'dürüst, saygılı, nazik, yardımsever, kadına değer veren, dikkatli, başarılı, şükreden' olarak nitelendirilmiştir. Öğrenciler sadece resimlerde erkeği özgür, özgüvenli, yüksek olarak nitelendirilmiştir. Erkek öğrencilerin metafor ve resimlerde kız öğrencilere oranla erkeklere dair olumsuz özellikleri yükleme sıklığı fazladır. Çalışmada kadın ve erkeklere olumsuz özellikler yüklenmiştir. Güder (2014)'in çalışmasındaki çocuklar genel olarak olumlu özellikleri erkeklere, olumsuz, yetersiz özellikleri kadınlara yüklemişlerdir bulgusuyla örtüşmemektedir. Çalışmanın öğrencilerin metafor ve resim çizimlerinde erkeği güçlü, sert, şiddet uygulayan, kırıp döken olarak nitelemesi bulgusuyla, Dikme ve Gökçe (2019) tarafından yapılan çalışmanın erkeğin "güçlü, öfkeli'" nitelendirilmesi bulgusu örtüşmektedir.

\section{SONUÇ VE ÖNERILER}

Güzel Sanatlar Lisesi Resim alanı öğrencilerinin cinsiyet kalıp yargılarının metafor ve resim çizme- yazma tekniğiyle incelenmesiyle şu sonuçlara ulaşılmıştır.

Kadın için 67 erkek için 80 metafor üretilmiştir. Erkeğe üretilen metaforlar daha fazla çeşitlilik göstermektedir. Kız ve erkek öğrencilerin kadını açıklarken ağırlıklı olarak bitki, erkeği açıklarken ağırlıklı olarak nesne kategorisindeki metaforları kullandığı görülmüştür. Metafor açıklamalarında ve resim çizimlerinde kız öğrenciler çoğunlukla kadını olumsuz özelliklerle nitelendirmemiştir. Kız öğrencilerin kendilerine yönelik alg1sı olumlu olduğu düşünülmektedir. Olumsuz özelliklerle erkeğin nitelendirilmesi kız öğrencilere göre daha fazla erkek öğrenci tarafından yapılmıştır. Resim çizimlerinde kız öğrenciler kadını özgür, özsaygısı yüksek, yetenekli, güçlü; erkeği dürüst, saygılı, kadına değer veren olarak nitelendirmiştir. Erkek 
öğrenciler kadını ev işleri yapan, çocuk bakımıyla ilgilenen, narin, duygusal; erkeği güçlü, koruyan, kahraman, çalışan, para kazanan olarak nitelendirmiştir.

$\mathrm{Bu}$ sonuçlar doğrultusunda çalışmanın "Güzel Sanatlar Lisesi resim bölümü öğrencilerinin cinsiyet kalıp yargılarını belirlemede metafor ve resim çizme-yazma teknikleri arasında fark yoktur", "Güzel Sanatlar Lisesi resim bölümü öğrencilerinin cinsiyetinin, cinsiyet kalıp yargıları üzerinde etkisi yoktur” hipotezleri yanlışlanmıştır.

Bireyin benimsedikleri cinsiyet rolleri, önce kendine dair oluşturduğu algıyı, sonra karşı cinse karşı oluşturduğu algıyı belirler, kimlik oluşumunu etkiler. Cinsiyet kalıp yargılarını doğduğu çevreden, okuldan, kitle iletişim araçlarından arkadaş çevresinden öğrenirler. Bu nedenle 'cinsel algılama kalıpları' yaşam boyu gelişim ve değişim gösterir. Cinsiyet rollerinin kazanıldığı, cinsiyet kalıp yargılarının şekillendiği önemli gelişim dönemlerinden biride ergenliktir. Bu dönemde olan öğrencilerin, sağlıklı cinsiyet rollerini üstlenmede, kendilerine ve karşı cinse olumsuz algıların tespit edilmesinde rehberlik etmeyi sağlaması için cinsiyetleri algılama biçimlerinin belirlenmesi gerekir. Ayrıca farklı toplumsal özelliklere sahip bölgelerde, tekrarlanarak, kadın ve erkeğe ilişkin ortaya çıkan kategorilerin benzeşip benzeşmediğinin araştırılması önerilir. 


\section{KAYNAKÇA}

Aslan, G. (2015). Öğretmen adaylarının toplumsal cinsiyet algılarına ilişkin metaforik bir çözümleme. Eğitim ve Bilim. Tedmem. Cilt 40 (2015) Sayı 181 363-384.

Başıbüyük, A. (2005). Doğu anadolu bölgesinde nüfusun cinsiyet ve yaş yapısı. Doğu Coğrafya Dergisi, 14, 67-94.

Bilgin, N. (2014). Sosyal Bilimlerde içerik analizi teknikler ve örnek çalışmalar. 3. Baskı, Ankara: Siyasal Kitabevi.

Büyüköztürk, Ş.(2016). Bilimsel araştırma yöntemleri. 22. Bask1, Ankara: Pegem Akademi.

Cüceloğlu, D. (2008). Insan ve davranışı.17. Basım, İstanbul: Remzi Kitabevi.

Dikme, E., Gökçe, T.A. (2019). Lise öğrencilerinin toplumsal cinsiyet algılarının incelenmesi. 14. Uluslararası Ĕ̈itim Yönetimi Kongresi Tam Metin Bildiri Kitabı - 2-4 Mayıs 2019 Şu kaynaktan ulaş1labilir https://www.researchgate.net/publication/335727541

Direk, N., Irmak, B. (2017). Dokuz Eylül Üniversitesi Tıp Fakültesi Öğrencilerinde toplumsal cinsiyet rollerine yönelik tutumlar. DEÜ Tip Fakültesi Dergisi, 31, 3, 121-128.

Dökmen, Z.Y.(2010).Toplumsal cinsiyet-sosyal psikolojik açıklamalar. 2. Baskı, İstanbul: Remzi Kitabevi

Esen, E. Soylu, Y., Siyez, D. M., ve Demirgürz, G. (2017). Üniversite öğrencilerinde toplumsal cinsiyet algısının toplumsal cinsiyet rolü ve cinsiyet değişkenlerine göre incelenmesi. $E$ Uluslararası Ĕgitim Araştırmaları Dergisi, Cilt: 8, Sayı: 1, 2017, ss. 46-63.

Filiz, B.S., Kanlı, Y., Üstündağ, İ., Demircan, B. (2018). Anadolu İmam Hatip Lisesi Öğrencilerinin Toplumsal Cinsiyet Algıs1: Ankara Hüseyin Gazi Anadolu İmam Hatip Lisesi Örneği. Turkish Studies Educational Sciences Volume 13/19, Summer 2018, p. 327-345.

Güder, Y. S. (2014). Okul öncesi dönemdeki çocukların toplumsal cinsiyet algllarının incelenmesi. Doktora tezi. Hacettepe Üniversitesi, Ankara.

İnanç, B.Y., Bilgin, M., Atıcı, K.M. (2004). Gelişim psikolojisi çocuk ve ergen gelişimi. Ankara: Nobel Kitabevi.

Kantoğlu, A., Çetin,Y.N., Erdoğan, A. (2018). Ergenlerde toplumsal cinsiyet algısının sosyodemografik özelliklere göre değerlendirilmesi. Konuralp Tip Dergisi 2018;10(2):175-187.

Karapekmez, S., Yıldırım, R.G., Akamca, Ö.G., Ellez, A.M., Üner, B. N.A. (2018). Okul Öncesi Dönemde Mesleklere İlişkin Toplumsal Cinsiyet Algısı. GEFAD / GUJGEF 38(2): 469-513.

Menekşe, N.F., Asan, A. (2019). 3-6 Yaş Arası Okul Öncesi Çocukların Oyuncak Tercihleri Ve Cinsiyet Kalıp Yargıları İle Ebeveynlerinin Toplumsal Cinsiyet Algıları Arasındaki İlişkinin İncelenmesi. Ístanbul Ticaret Üniversitesi Sosyal Bilimler Dergisi Y1l:18 Say1:35 Bahar 2019/1 s.821-836.

Sakallı Uğurlu, N., Türkoğlu, B. (2016). Günümüz Türkiye'sinde cinsiyet kalıpyargıları: Kadın kimdir? Erkek kimdir? I. Sosyal Psikoloji Kongresi, Başkent Üniversitesi. Şu kaynaktan ulaş1labilir https://www.researchgate.net/publication/310954437

Sargın, N. (2018). Üniversite öğrencilerinin kadın kavramına ilişkin metaforları: Necmettin Erbakan Üniversitesi örneği. Ĕgitim ve Öğretim Araştırmaları Dergisi, 7 (2). şu kaynaktan

ulaşılabilir http://www.jret.org/FileUpload/ks281142/File/03.nurten_sargin.pdf

Sözer, M.A., Özkan, R.(2014). öğretmen adaylarının kadın olgusuna ilişkin algılarının belirlenmesi. Uşak Üniversitesi Sosyal Bilimler Dergisi 7(1), 264-278. 
Topuz, K.S., Erkanlı, H. (2016). Toplumsal cinsiyet bağlamında kadın ve erkeğe atfedilen anlamların metafor yöntemiyle analizi. Alternatif Politika, 8 (2), Nisan. Şu

kaynaktan ulaşılabilir http://alternatifpolitika.com/site/dosyalar/arsiv/Nisan2016sayi2/4.pdf

Tuğrul-Gezer, Y. (2018). Erken yaşta evlendirilen kadınların evlilik süreçleri, deneyimleri ve sonraki yaşamları üzerine nitel bir çalışma. Sosyoloji Notları 2(1), Şu kaynaktan ulaşılabilir https://dergipark.org.tr/tr/pub/sosnot/issue/37831/423671

Türkmen, D., Alptekin G. (2020). Ergenlerin toplumsal cinsiyet eşitliğine ilişkin tutumlarının belirlenmesi: Eskişehir Örneği. Uluslararası Dil, Eğitim ve Sosyal Bilimlerde Güncel Yaklaşımlar Dergisi (CALESS),2(2), 608-629.

Yeşilkayalı, E., Köksal, S., Kılıç, M., Dursun, B., Aybir, C. (2019). Sosyal hizmet bölümü öğrencilerinin toplumsal cinsiyet bağlamında kadın algısı: metafor analizi örneği. 6.Uluslararası Sosyal Beşeri ve İdari Bilimler Sempozyumu Özet Bildiri Kitapçığı 18-1920 Nisan, Alanya. 